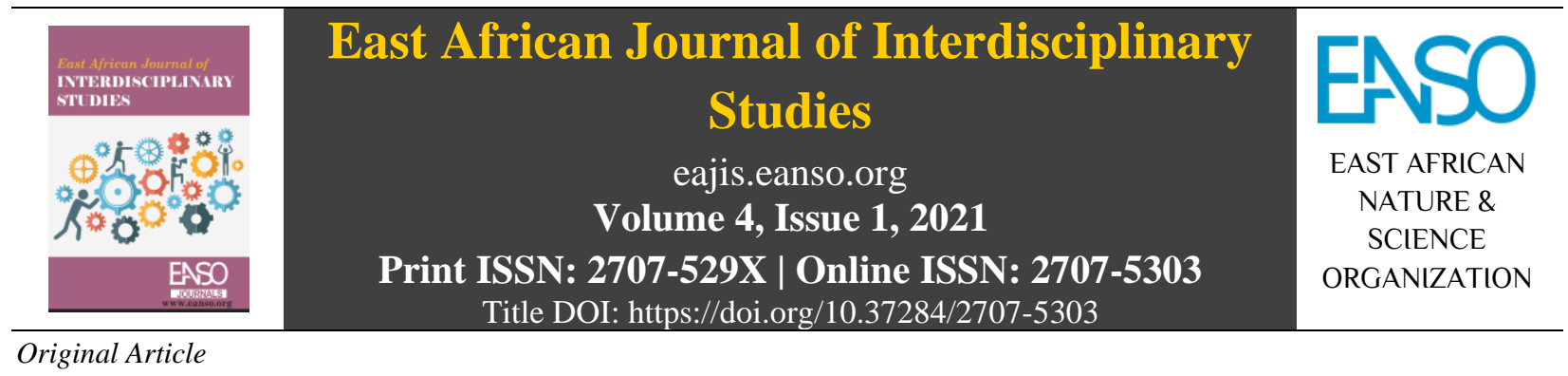

\title{
Role of Character-Leaders in Development as Depicted in Swahili Literary Texts.
}

\author{
Oiko Fridah Gesare ${ }^{1} \&$ Martha Nyangweso Syekei ${ }^{1 *}$ \\ ${ }^{1}$ Rongo University, P.O. Box 103 - 40404, Rongo, Kenya. \\ *Author for Correspondence Email: marthanyangweso83@gmail.com
}

Article DOI: https://doi.org/10.37284/eajis.4.1.477

\section{Date Published: ABSTRACT}

19 November 2021 It has always been believed by the majority that elected leaders are a necessary component in the development of any country and more so in the

Keywords: developing world. This is so strong in that leaders are elected by their people through a competitive election because they believe they will influence

Leaders, economic development positively. Writers of literature are born and bred in

Economic Development, the communities where they equally participate in the process of electing their

Swahili Literary Texts, leaders. Thus, when they write about the maxima or minimal roles played by these leaders in impacting economic development, they are believed to LDCs. portray a true and to some extent a believable picture of the state of development in their respective communities. In this respect, this paper analyses the role played by the elected leaders in the realization of economic development in the third world as portrayed in selected Swahili literary texts. To achieve our main objective, the paper surveys the challenges of the third world and shows how the elected leaders tackle them to realize economic success. The paper concludes that elected leaders have downplayed their role in enhancing economic development and the result is underdevelopment experienced in the third world worse than that of the colonial leaders.

\section{APA CITATION}

Gesare, O. F., \& Syekei, M. N. (2021). Role of Character-Leaders in Development as Depicted in Swahili Literary Texts East African Journal of Interdisciplinary Studies, 4(1), 21-30. https://doi.org/10.37284/eajis.4.1.477.

\section{CHICAGO CITATION}

Gesare, Oiko Fridah, and Martha Nyangweso Syekei. 2021. "Role of Character-Leaders in Development as Depicted in Swahili Literary Texts". East African Journal of Interdisciplinary Studies 4 (1), 21-30. https://doi.org/10.37284/eajis.4.1.477.

\section{HARVARD CITATION}

Gesare, O. F., \& Syekei, M. N. (2021) "Role of Character-Leaders in Development as Depicted in Swahili Literary Texts", East African Journal of Interdisciplinary Studies, 4(1), pp. 21-30. doi: 10.37284/eajis.4.1.477.

\section{IEEE CITATION}

O. F. Gesare, \& M. N. Syekei, "Role of Character-Leaders in Development as Depicted in Swahili Literary Texts", EAJIS, vol. 4, no. 1, pp. 21-30, Nov. 2021.

21| This work is licensed under a Creative Commons Attribution 4.0 International License. 


\section{MLA CITATION}

Gesare, Oiko Fridah, and Martha Nyangweso Syekei. "Role of Character-Leaders in Development as Depicted in Swahili Literary Texts". East African Journal of Interdisciplinary Studies, Vol. 4, no. 1, Nov. 2021, pp. 21-30, doi:10.37284/eajis.4.1.477.

\section{INTRODUCTION}

From time immemorial man has faced the challenge of taming the environment for his survival. By aggressive tactics, man has been showing development aspects on earth. This can be witnessed in his lifestyle by which man felt it was necessary to domesticate animals and plants in order to have food security in harsh weather conditions. It did not end there, he later found security by living in groups which translated to communities. As men multiplied and became more, they needed organization on mechanisms of conquering the environment for a comfortable life that will eventually make them even happier. This brought the need for a leader to help men to work effectively towards achieving the goal of development. This means that development has been the ultimate goal for mankind. In this paper henceforth development denotes economic development.

According to the Oxford Dictionary, a leader is a person or thing that holds a dominant or superior position within its field and is able to exercise a high degree of control or influence over others. Thus, a leader, in this context, elected one, is bestowed with the sole responsibility of influencing the development of a country towards achieving her goals. This means that leaders have the sole role of helping their people solve various challenges that hinder development by motivating them in a well defined channel of policies.

Leadership is a widespread component but it is the quality that is key in maintaining the development of a country. This is the main reason why elected leaders come in handy particularly in matters of influencing and steering the economic development in their countries. This is because they play a critical role in helping people stay on course towards achieving the goal of development. This means that leaders thus are a necessary ingredient in the economic advancements achieved in their countries. Therefore, these two elements are inseparable as they are two parts of the same coin.
The role of leaders as a key factor in determining the type of economic development in a country is as old as mankind, hence its much attention by many scholars especially from the literary world. Literary writers as Bonafede members of the society use literature as a platform to give their views on how leaders have influenced development either positively or negatively. To illustrate the path of our analysis we will borrow one example from the literature of the Bible touching on the role of leaders in the economic progress of their territories. In Genesis 41, Joseph after interpreting Pharaoh's dreams is put in charge of Egypt. In other words, he is the leader of the land. Pharaoh tells him “... I hereby put you in charge of the whole land of Egypt" (Genesis 41:41).

This was as a result of the belief that Joseph could lead the land of Egypt out of the crisis of hunger that lay ahead of them. Joseph as the prime minister led his people with the help of his commissioners by motivating them in collecting all the food that was harvested in the years of abundance and stored in cities. This translated to food security.

As such, then economic development is the process of building strong structures that enable a population of a given country to live a good life through proper and equitable distribution of economic resources (United Nations Development Program and henceforth UNDP). The structures involving good life include but are not limited to education, health, employment, religion, and media. For this to be achieved effectively, elected leaders become a necessary component in creating and communicating a clear vision to their people with an aim of encouraging them to work towards achievements. As such their leadership skills will determine the successes or failures in their countries. This paper has much interest in elected leaders since they are the ones in charge of formulating and implementing policies for the benefit of the people who elected them.

With respect to the above examples, this paper investigates the role of leaders in development. As such, we intend to analyse the recipes that directly 
or indirectly affect development in the third world and the interaction with the elected leaders in respect to whether they help economic development as portrayed in selected Swahili literary texts. In this context, Swahili literary texts refer to literature materials written in Kiswahili which are focusing on the leaders' engagement in the structures of development.

Developing countries or third world, less developed countries, or even underdeveloped countries, have been defined as nations with less developed industrial bases and a low human development base (UNDP). Simply put, it refers to countries whose majority of the people live in miserable conditions. In this paper, we have used Less developed Countries henceforth, (LDCs) to encompass all the names referring to the poor countries in terms of economic prosperity. This is because the survey in literary works does not give a hope of seeing the poor countries ever becoming better in terms of development.

This paper has focused on literary texts since in literature writers express themselves freely and openly through various styles thus giving us a true picture of the state of the society in development terms. Unlike interviews, where leaders can be biased and lie about developmental achievements, literature gives us an opportunity to see our leaders and people surrounding them, in this case, advisors in a more elaborate manner. This is because literature offers a platform that enables us to assess their thoughts and actions freely far away from the interference of the external conditions where they can camouflage their characters. As such the best way to measure this is by surveying the leaders' interaction with the various recipes of development as follows:

\section{EDUCATION AND EMPLOYMENT}

The Oxford Dictionary defines education as the act or process of imparting or acquiring particular knowledge or skills, for a profession. Education in every sense is one of the necessary components in development. This is in agreement with Ozturk's (2001) declarative statement where he says " “...No country can achieve sustainable economic development without substantial investment in human capital..."
This means that it is an investment in quality education that helps a country to develop and not merely its acquisition. What is implied here is that education alone does not necessarily transform the economy but it is the quality and relevance to a country's needs. Thus, here we are solely concerned with answering the question 'Does education contribute to economic development?' This paper through examples from the selected texts shows clearly that education in LDCs has played a minimal role in development.

Education as an ingredient of development, not only equips people with understanding but as well as improves their lives which translates to the overall development of the society. This is because education has an important role in contributing to technological capabilities and change in people. Education in the third world is faced with many challenges that leaders have failed or rather ignored to address. Education has and still faces the challenge of teacher absenteeism where teachers abscond duty but stay on the payroll as active teachers. In Ken Walibora's novel Kidagaa, Mashaka tells his uncle Majisifu who doubles to be her Kiswahili teacher how his absence has denied them an opportunity of learning in his subject. This conversation between Mashaka and Majisifu elaborates the effects of absenteeism in education as follows:

"Habari za Masomo Mashaka? Majisifu alimuuliza baada ya kitambo. "Nzuri ila twakuona kwa nadra sana," ... "Hatujasoma lolote katika somo la Kiswahili karibu muhula mzima" (uk. 47). ["Mashaka how are you fairing on academically?" Majisifu inquired briefly. "Fine, but we rarely see you in class," ... "We haven't learnt much in Kiswahili for almost the whole of this term" (p. 47)]

Majisifu has not faced any disciplinary action from the concerned authorities. Though his brother Nasaba Bora is the Chief of Sokomoko, he has not taken any positive measures in addressing the issue. When people earn without working, they derail the development of a country as opposed to developing it.

Apart from absenteeism, we have irrelevance of the curriculum as another big challenge in the education sector. Most LDC's are either agricultural or

23 This work is licensed under a Creative Commons Attribution 4.0 International License. 
mineral-based economies. As such, for them to advance economically the workforce must be equipped with skills and knowledge on how to exploit minerals and develop the agriculture sector. But the curriculum that is offered has no relevance to the needs in LDC's and this is the reason why the learners are worried about the application of what they have learnt and its significance in the labour market. This is evidenced by the question posed by a learner to his teacher in S. A. Mohamed's play, Amezidi:

"Hivi... hivi baada ya kukariri mawazo ya Archimedes kwa miaka mingi, kwa nini hatujaweza kuunda nyambizi?" (uk. 30). [“Ok ... now after reciting Archimedes' Principle for decades, why haven't we been able to construct a submarine?" (p. 30)]

This means that students will graduate with skills that are inadequate and irrelevant to the requirements of development in LDCs. This does not only derail but stifles development since we do not expect a half-baked workforce in terms of skills to develop an economy that is wanting. Mohamed explicitly demonstrates this in his play Amezidi whereby the engineers recruited recently from universities are unable to repair a boiler. If companies do not have what it takes to produce effectively, the result will be low production and this will definitely hamper the economic progress yearned for by the LDCs. The assistant boss says this about the fresh graduates who were recently employed:

Wanasema walifundishwa nadharia tu ... (uk. 42). [They claim that they were only taught theories ... (p. 42)]

This means that experts will be hired to fix the boilers at a cost that is expensive to an economy that aspires to develop. Because of inadequate skills in different fields, many university graduates have remained unemployed and if lucky, secure menial jobs. This has translated to high levels of crime and welfare dependency. In Arege's play, Chamchela, the fresh graduates are only able to secure menial jobs which are totally below their qualifications. Rukia, a character in the play Chamchela laments on the state of their living:
... Eeh? Kisomo tunacho lakini tunakaa...kama... kama nini sijui. Pamoja na elimu yote hii? (uk. 30). [Eeh? ... even if we are graduates we are living in very deplorable conditions. Does our education make sense at all? (p. 30)]

Though in a poor state, they are lucky to have menial jobs where they are paid meagre salaries. The majority are jobless and this has led to frustration and the result is the manipulation by leaders in the fulfilment of their wishes. Instead of opting for long-lasting solutions to the crisis in unemployment in LDCs, elected leaders have opted to use the young and fresh graduates as a way of intimidating the few who are employed when they go on strikes because of poor working conditions. This is witnessed in Arege's Mstahiki Meya, when Sosi who is the Mayor of Cheneo Municipality, on getting news of the looming strike of workers says this:

Kuna vijana wengi wasio na kazi ilhali wamehitimu kutoka vyuo vikuu fresh kabisa. Wanaoleta siasa wapewe barua za kuwatimua na kuwakumbusha kuwa kazi wanazofanya si zao bali ni za Baraza la Cheneo (uk. 21). [There are so many fresh graduates who are currently unemployed. Those who are engaged in cheap propagandas should be aware that they risk their jobs since they are serving the municipality (p. 21)].

Such utterances from a leader whom people trust will be of help in solving their problems and steer development is a sign in itself that LDCs may not prosper.

Leaders have really downplayed their role in solving the challenges facing the education sector. Instead of dwelling on finding solutions to the messes in education, they have opted to educate their children elsewhere and mostly in DCs where the education sector is developed. This shows that leaders are aware of the plight of education but are reluctant to act. Quality education is mandatory for any country that aims to develop its people. This is because learned people are able to approach societal challenges and thus promote development rather than engage in strikes. But we cannot achieve this by educating a few individuals as leaders are doing. In Ken Walibora's novel, Kidagaa Kimemwozea,

24| This work is licensed under a Creative Commons Attribution 4.0 International License. 
Mr. Nasaba Bora's son Madhubuti is educated in Russia for his degree. This is evidenced by Nasaba Bora's son who is in Russia for his further studies. This is evidenced by Nasaba Bora's son who is in Russia for his higher education:

...Hujambo? Mimi sijambo huku Urusi. Ninakushukuru sana kwa kuniwezesha kuja huku ughaibuni ili nipate elimu ya juu... (uk. 87). [How are you? I am fine here in Russia. I would like to thank you for awarding me the opportunity come overseas further studies... (p. 87)].

Education for a few means that the majority will be illiterate and this will result in low production. This will do more harm than good to development. The educated few who secure jobs are the ones who engage in corruption because they interact fairly with the structures of development. Corruption is a widespread vice all over the world but is more pronounced in LDCs. Mayor Sosi, in Arege's play Mstahiki Meya, as an elected leader, is a participant of corruption as opposed to condemning the act. When the Preacher calls in to pray for the mayor, he is bribed in the form of an offering. This is what the mayor says:

Pia Baraza litatoa sadaka ya shilingi laki moja kila mwezi. Watu wengi hawatambui mchango mkubwa wa wahubiri. Chini ya uongozi wangu Baraza hili litajitolea kutambua mchango wa wahubiri (uk. 44). [The municipality shall also give an offering of a hundred thousand shillings every month. Many people are not aware of the significances of preachers. Under my leadership, this Municipality will ensure that preachers are recognized accordingly. (p. 44)]

The Preacher accepts the offer as much as the people are suffering. As a religious leader, he is supposed to rebuke the evils of the elected leaders and not join hands in acts that do not necessarily promote development and the well-being of the people.

\section{HEALTH AND DEVELOPMENT}

Being healthy means a complete state of physical, mental, social well-being including the absence of (WHO). Health is one of the major elements for development. Our perception is mandated by the view that health touches directly on a people's well- being. No wonder we have the say 'health is wealth'. Much research has proved beyond doubt that health is a key determinant in achieving development and poverty eradication. This implies that for any economy to flourish, health must be the major concern for leaders. The leaders are bestowed with the sole responsibility of taking measures that will ensure the burden of diseases is lessened by giving children healthy childhoods thus increasing life expectancy. This will in turn result in people free from diseases, who will be available to work and this will boost the economy positively.

Health is a crucial tool for economic development because it determines the productivity rate. When people are sick, it means they will not work but rather seek medical attention, this translates to low production, and when people are not producing but consuming, we only talk of economic underdevelopment and not vice versa. Noting the importance of health to development is quoted by Madi \& Hussain (2007):

'Improving the health and longevity of the poor is an end in itself, a fundamental goal of economic development. But it is also a means to achieving other development goals related to poverty reduction. The linkage of health to poverty reduction and long-term economic growth is much stronger than is generally understood...'

This shows that health is very important for any country to achieve economic progress. Though this is the case, the health sector in LDCs is in a wanting state. There is less trained personnel to handle many patients. In Arege's play, Mstahiki Meya, we find a doctor and a nurse serving a large crowd of people and the nurse by the name Waridi complains to a patient who wants to skip the queue:

Lazima ufuate utaratibu. Huoni mstari ulivyo mrefu hapo nje? au unadhani hao wengine hawakuja kutibiwa? (uk. 3). [You have to queue. Aren't you aware that the queue is long? Are you ignoring the fact that others (patients) are here too for treatment ? (p. 3)].

This means that services to the patients will be slow as they have to wait for long before being attended. The situation is worsened by the absence of drugs as Siki the hospital doctor instructs Waridi, the nurse is saying:

25 This work is licensed under a Creative Commons Attribution 4.0 International License. 
...Watakufa kwa kukosa dawa, si kwa kukosa tumaini. (Kama aliyekumbuka kitu). Waridi, andaa mchanganyiko wa sukari na chumvi katika maji moto. Huenda itasaidia kidogo... (uk. 7) [ ... they will die due to the absence of drugs but not hope (As if recalling about something) Waridi, prepare a mixture of sugar and salt in warm water. It may help. (p. 7).]

We cannot develop an economy when people who are supposed to work and produce are in hospitals seeking medical attention which is not available. Leaders have ignored the health sector. They have instead made efforts to seek medical attention overseas for their families and friends. In Mstahiki Meya, a play by Arege, the Mayor by the name Sosi as an elected leader has flown his wife and children overseas for medical attention at the expense of his people who are suffering. He tells Bili, his spy this:

Ndiyo maana alisafiri ng'ambo. Madaktari wetu hawa wa kubabaisha tu. Kule ng'ambo ndipo walipo wakunga wenyewe. Sikutaka kubahatisha. Halafu tena mtoto akizaliwa huko anapata uraia wa huko urea (uk. 27). [That is the reason she (Mayor's wife) travelled there (overseas). [That is the reason she (Mayor's wife) travelled there (overseas). Our doctors are just scrappy. Overseas is where there are real midwives. I did not want to risk. And then when a child is born overseas, they automatically become citizens. (p. 27)]

This means that funds that could have been used to improve the health sector are diverted for personal use and the benefit of the elected leaders' next of kin. In this manner, we can conclude that leaders are not focused on impacting positively on the development of the majority who elected them but rather on personal interests.

Health is achieved by food consumption which translates to financial stability. Children from disadvantaged backgrounds reach adulthood with chronic illnesses that affect their ability to work. This will hamper production since only healthy people have the energy to work and increase production effectively. Thus, the future abilities in income creation will be hampered and the result will be underdevelopment as opposed to development. In Arege's Mstahiki Meya, workers of the municipality cannot afford to buy quality food and this has led to kwashiorkor in their children. We will not develop an economy whereby the future generations have already been doomed by illnesses that are a result of malnutrition. This is shown when a patient is brought to a hospital and the doctor has to say:

(Anamtazama nesi kwa makini zaidi). Tatizo ... la utapiamlo lipo. (uk. 6). [(Looking keenly at the nurse). It's the issue of... malnutrition (p. 6)].

When people are working and yet cannot afford a proper diet for their children, then it is a sign that leaders are not focused on the wellbeing of their people.

\section{RELIGION AND DEVELOPMENT}

Religion as a structure of development is very significant in any state since it is mainly concerned with the cultivation of morals in the people of any society to live in just ways. Religion fosters unity and understanding, thus, if well manipulated, can impact positively on the development of any society. Religion in LDCs is not the same thing as God as it has been used for exploitative ways. Leaders in LDCs have used religion as a shield in which they camouflage their evil deeds to the society at large. During the colonial times, the colonialists used religion as a tool of exploiting the Africans as evidenced in Thiongo and Mirii's play Nitaolewa Nikipenda, where Gicaamba one of the characters notes this:

...Wamishenari wa madhehebu yote Walichukua bibilia kwa mkono wa kushoto, Na bunduki ikiwa mkono wa kulia. Mzungu alitake tulewe dini Huku yeye, Kwa wakati huu, Alikuwa anapima na kunyakua mashamba yetu, Na kuanzisha viwanda na biashara. Kwa jasho letu. (uk. 56). [... All the missionaries from all denominations Held the bible by the left hand, And the gun in the right hand. The white man wanted us to be drunk in religion while he, In the meantime, was mapping and grabbing our land, and starting off factories and businesses at the expense of our sweat. (p. 56)].

The colonialists as such, used religion as a tool to enrich themselves and their home countries at the expense of Africans. This led to underdevelopment 
in Africa. The role played by religion in Thiongo and Mirii's play Nitaolewa Nikipenda is what is imitated in Arege's Mstahiki Meya whereby the church leader who is supposed to condemn the evil actions of corruption of the mayor, Sosi, the protagonist of the play, praises him and thus perpetuates the evil by being corrupted in the name of offerings. This clearly shows that elected leaders too have followed suit in using religion as a tool for personal nourishment as opposed to societal growth. Maksuudi too as the leader in S. A. Mohamed's novel (Utengano), uses religion to shield his devilish acts in the society. Kazija, a prostitute he has gone to check out tells him this:

'Na watu unawadanganya kama wewe shekhe, na wengine unawadhulumu, uafriti na udhalimu kwa wanawake... na yote hayo...' (uk. 11). ['And you deceive people that you are a sheikh (priest), but you have oppressed many and have committed all sorts of evil more so to women...' (p. 11)].

This is not an act of development by leaders but, underdevelopment since leaders are not using religion for the wellbeing of the majority who are suffering in society. Religious leaders are supposed to rebuke evils in society with an aim of instilling discipline and responsibility and not vice versa.

In Walibora's novel, Kidagaa Kimemwozea, Nasaba Bora reads the bible in his house but does more evils to the people whom he is supposed to protect. He oppresses the poor by grabbing their land by unjust means as well as ignoring the plight of the needy in society. In this sense, religion is used by leaders to scare the public scrutiny of their evils in society. This is what Balozi (the Ambassador) says about Nasaba Bora on Heroes' Day celebrations:

...Kiongozi aliyeteuliwa na Mwenyezi Mungu. Yeyote ajaribuye kumpinga anapingana na kudura ya Mwenyezi Mungu... (uk. 68). \{... A leader chosen by God. Whoever who is against him is against the will of God... (p. 68)].

Although Nasaba Bora's character is not Godly, the mention of religion in his capacity as a chosen leader is to ensure that people believe and trust in him so that they do not challenge his inefficiency in promoting development.

In Kezilahabi's novel Gamba la Nyoka, elected leaders collaborate with religious leaders to oppress the poor in society. This is vividly demonstrated when Mamboleo and Mambosasa, as village elites take Priest Madevu into task about his crookedness in the name of religion in order to exploit Africans, he is annoyed and this threatens his survival in Tanzania. He opts to run to the District Commissioner, whom he compromises and as such when the two elites arrive to report him, they are too late and are not even allowed to explain themselves but rather punished severely. This is what the DC says in order to intimidate and humiliate their efforts (Kezilahabi, 2006).

"Ninyi vijana hamjui kwamba katiba ya TANU inaheshimu dini! Hamna akili ninyi! Mnasoma mawazo ya Marx kama kasuku halafu mnayaleta hapa Tanzania! (uk. 68). ["Young men you are not aware that the Tanu constitution accords much respect to religion! You bastards! You think that your little understanding of Marx's theory can work in Tanzania! (p. 68)].

With this evidence, then we can say that religion though meant to promote development has been used as a tool by leaders to underdevelop LDCs. As such this has led to mistrust in religious leaders. When every recipe that is connected with development is not performing its mandates accordingly, then it will impact negatively on the other recipes and the result will be underdevelopment.

\section{MEDIA AND DEVELOPMENT}

The revolving literature shows clearly that the media's role is very significant to the development of society. This does not mean that the other structures like employment, health, education, and religion are not crucial. It only recognizes the critical role of the media in disseminating information to society.

The media plays a fundamental role in informing the people of the realities of the state of economic development in their society. For the media to achieve this goal, it has to expose and reveal the positive effects as well as negative ones of the 
leaders without bias. The media also should serve as a platform where the citizens air their voices to their leaders. All these are only possible if the media works without interference from the government and other interested parties.

For the media to perform its functions well it must disseminate information without fear of the government and interest groups. In the third world, the elected leaders are not willing to let the media perform its duties of informing the public about the state of development in their territories. They have interfered with media freedom. For instance, in Arege's, Mstahiki Meya, The Mayor avoids a conversation with the journalists since he is aware of their intention. This is evidenced in the conversation with his servant, Gedi as follows:

Gedi: Wale wapuuzi wa kawaida. Wale wadukuzi. (The common bastards. The journalists.)

Meya: Wanahabari? (The journalists?)

Gedi: Kukuhoji kuhusu mgomo. (To interview you about the ongoing strike.)

Meya: Waambie niko mkutanoni. (uk.33) (inform them that I'm in a meeting.) (p. 33)

When leaders evade interviews by the media, it means that we cannot be able to get the truth regarding the state of development in the society since we solely depend on them as the policy implementers.

In the third world, the media is one of the highly corrupted recipes of development by the elected leaders since it is the main domain that reaches the society. Olken and Pande (2012b) attests to this when he says:

'... amongst the highly bribed recipes of economic development is the media, where bribes to control the media were of magnitude larger as much as USD 1.5 million per month for one television station's support.' (p. 7)

The effect of such influence makes the information disseminated distorted and thus not reliable. When this happens, the media disseminates distorted information in order to please the leaders and not in light of highlighting developmental issues as they are. For example, in Arege's Mstahiki Meya, the media gives false information about the arrival of drugs in the hospital and this leads to the death of many innocent poor patients. This is in accordance with the false promises by leaders that the muchawaited drugs will be availed to hospitals soon. This is what the mayor says:

Meya: Ahadi zetu zimetufaa hadi sasa. Atajua nani ukweli ila wenyewe myaseme huko? (uk. 21)

Mayor: Our (empty) promises have been of great help. Who will unveil us unless one of us does it? (p. 21)

Mayor: Our (empty) promises have helped us so far. Who will know the truth unless you say out there? (p. 21)

We cannot progress economically when the media propagates lies in liaising with the elected leaders. This leads to mistrust in the media information. Also, in Walibora's, Kidagaa Kimemwozea, Nasaba Bora as the chief of Sokomoko manipulated the media for personal gains as opposed to propagating information on development matters. This is what he says when he receives a newspaper from the postman:

...Ukurasa wa mbele ulikuwa na picha na habari zilizohusiana na sherehe za Sikukuu ya Wazalendo. Aliitafuta picha yake akaikosa. Akaamua kwamba atampigia simu mhariri mkuu wa Tomoko Leo baadaye kumuulizia kwa nini. Nduguye Majisifu alipokuwa mhariri wa gazeti hilo kumbe mambo yalikuwa sahali yakatawasari. Aliweza kutokea gazetini kila alipopenda.... (uk. 87). [... The front page was mainly covered with photos and information pertaining to Patriots Day. He perused for his photos but could hardly find it. He decided to find out from the editor of Tomoko Daily for the missing photo. This was unusual because, when Majisifu, his brother was the chief editor of the newspaper, his photo was a norm in the newspaper at his will. (p. 87)]

This means that elected leaders have much control in the media as such the media is denied an opportunity to perform its functions effectively of disseminating truthful information. As such, the media fails to inform the public about the vices of their government since they have already been

28| This work is licensed under a Creative Commons Attribution 4.0 International License. 
compromised. The result is under development since the media has away from serving the public to become the elected leaders' servants. This means that the media disseminates information guided by the wishes of the leaders which is usually not development-oriented.

\section{CORRUPTION}

Corruption is a vice that touches on all the recipes of development and affects them negatively. Corruption has significant adverse effects on economic development since it alters the efficiency levels and undermines integrity among a people of a country. This is what is echoed by Olken and Pande (2012a), when they say:

Corruption is very detrimental to any economy that aspires to grow. This is the reason why there has been much research in the last decade on corruption since it is increasing rapidly.

This means that corruption does not undermine development but curtails the effectiveness in the various recipes of development as well. Leaders are to play a major role in taking measures and putting mechanisms in place to curb this vice. This is because they are to be role models to people in promoting development. But this is not the case in the third world (LDCs) as leaders have been the major participants in corruption as opposed to curbing as evidenced in literature In Walibora's, Kidagaa Kimemwozea, Chief Nasaba Bora did not get the land he owns through just means but through corruption. This is shown as follows:

Bwana Nasaba Bora alikuwa miongoni mwa Waafrika wachache waliojua mizungu ya "kurithi" ulwa na mali baada ya kuondoka Wazungu (uk. 13). [Mr. Nasaba Bora was amongst the few Africans who knew the dubious means to prosperity and wealth after the departure of colonialists (p. 13)].

Through corruption, Chief Nasaba Bora has acquired his wealth. This has led to many people suffering since he he is directly involved in their misery. This is not an act endeavoring to promote development. Corruption also deters development by undermining a government's ability to serve people since it corrodes the rule of law and public institutions. In Arege's, Mstahiki Meya, Bili, one of the mayor's advisors aids the Mayor in bribing a contractor whose services were terminated unprocedural through the court. This is what Bili says:

Hamna. Akutie nani ndani? Hakimu ataamuru alipwe fidia. Tena sio wewe wa kulipa. Baraza lenyewe litalipa maana ulichukua hatua kwa niaba ya Baraza. Kumbuka mtumwa hauawi. Muhimu ni kukubaliana naye kuhusu fungu atakalokupa kutokana na pato lake. Ukitaka hata unaweza kumtuma wakili wa Baraza waiendeshe kesi naye. Hapo mtakubaliana akupe fungu lako baada ya kumlipa (uk. 29-30). [Nobody will jail you? Ruling will be made in his favour but you will not be affected since the Municipality will shoulder the cost of compensation. Remember you are a servant and servants are to be spared. The most important thing is to agree on the modalities of sharing the proceeds. At your own discretion, you can hire the Municipality's lawyer to take over your case at a fee which he shall get when the deal is sealed up. (p. 29-30)].

This means that the government is going to lose its finances through the unscrupulous leader, Meya (Mayor). As such, finances that could have supported the development of other recipes for the sake of development will end up in a few individuals' pockets. This will translate to poor services in public offices and mistrust in leaders. And when people no longer trust their leaders then the chances of releasing their potential for development will be minimal.

Education is to give individuals of a community the necessary skills in order to enhance economic progress by ensuring an effective and quality workforce. This is thought since in LDCs, the educated where leaders are included, form the bulk of the ones involved in corruption. For instance, in Mohammed's Amezidi, Ame and Zidi as the Boss and Secretary respectively who are entrusted with the powers of managing and developing the company to prosperity engage in corruption when they make long lists of office materials to purchase non-existing items. This is what the Boss says:

Orodha ndefu... orodha nono ... (Anarudia mara nyingi.) Orodha ndefu... orodha nono... nipe mji (uk. 44). Long list... big list ... ( $\mathrm{He}$

29| This work is licensed under a Creative Commons Attribution 4.0 International License. 
recites it repeatedly.) Long list... big list... choose for me a town (signal for corruption) (p. 44)].

This is a true picture of what happens in the public sector of LDCs where long lists are made not for the purpose of purchasing materials to aid development, but rather in enriching a few greedy individuals. And this goes a long way in denying the majority of the essential services they are in dire need of. We cannot achieve prosperity in development when the educated have diverted their energy and skills to corruption at the expense of development.

\section{CONCLUSIONS}

Let us confess here that it has been tough to illustrate the recipes of development separately since they correlate closely as they affect each other and form a vicious cycle. For instance, the recipe of education will directly influence employment and employment and health directly whereas corruption affect all the recipes at different levels. As such, there seems to be no distinct boundary in the extent to which these recipes act independently. They work in a continuum. Although this is the case, we have clearly shown the role played by leaders in the various recipes of development. It is clear from the texts that leaders are the major obstacles to development in LDCs. Through literary texts, this survey has clearly indicated that leaders and in this case elected leaders have had a big hand in the underdevelopment that is being experienced in the LDCs. As Rodney (1981) notes that Europe underdeveloped Africa, so do we conclude that elected leaders underdeveloped LDCs in the tag of "development".

\section{REFERENCES}

Arege, T. M. (2007). Chamchela. Nairobi: J.K.F. Arege, T. M. (2009). Mstahiki Meya. Nairobi: VideMuwa.

Kezilahabi, E. (2006). Gamba la Nyoka. Nairobi: Fotoform Ltd.

Madi, H. H., \& Hussain, S. J. (2007). The role of health promotion in poverty reduction. EMHJEastern Mediterranean Health Journal, 13 (6), 1249-1255, 2007.

Mohamed, S. A. (1980). Utengano. Nairobi: Longhorn publishers Ltd.
Mohamed, S. A. (1995). Amezidi (Vol. 40). East African Publishers.

Olken, B. A., \& Pande, R. (2012a). Corruption in developing countries. Annu. Rev. Econ., 4(1), 479-509.

Olken, B. A., \& Pande, R. (2012b). Lifting the curtain on corruption in developing countries. VOX. https://voxeu.org/article/lifting-curtaincorruption-developing-countries

Ozturk, I. (2001). The role of education in economic development: a theoretical perspective. Journal of Rural Development and Administration, XXXIII (1), 39-47.

Rodney, W. (1981). How Europe underdeveloped Africa. Perspectives on Africa. Blackwell, Malden, MA.

Thiongo, N. \& Mirii, N. (1984). Nitaolewa Nikipenda: Mchezo wa Kuigiza. East African Publishers

Walibora, K. (2012). Kidagaa Kimemwozea. Nairobi: Spotlight Publishing Ltd.

$30 \mid$ This work is licensed under a Creative Commons Attribution 4.0 International License. 